\title{
ENTREPRENEUR
}

Jurnal Bisnis Manajemen Dan Kewirausahaan

Program Studi Manajemen Fakultas Ekonomika dan Bisnis Universitas Majalengka

Published every January and July e-ISSN : (2776-2483), p-ISSN: 2723-1941

Available online http://ejournal.unma.ac.id/index.php/entrepreneur

\section{Pengaruh Komitmen Organisasional dan Kepuasan Kerja Terhadap Kinerja Karyawan Perusahaan Daerah Air Minum Kabupaten Majalengka}

\author{
Endah Prihartini ${ }^{1}$ dan Yeyen Nitakomala ${ }^{2}$ \\ Fakultas Ekonomika dan Bisnis Universitas Majalengka \\ e-mail : endah@unma.ac.id
}

\begin{abstract}
In this research was conducted at the Central Perusahaan Daerah Air Minum of Majalengka Regency. The purpose of this study was to determine how the commitment, organizational and influence of job satisfaction on employee performance both partially and simultaneously.

This research uses a survey method with descriptive and verification analysis. The technique of data collection done by giving a questionnaire. The population in this study is the Central Perusahaan Daerah Air Minum of Majalengka Regency with 49 respondents. Testing the research. Testing the research instrument is done by testing the validity and reliability test using a Likert scale. Data analysis tool use classic assumption test, multiple linear regression analysis, coefficient of determination analysis, $t$ test, and $F$ test.

The result of this indicate that commitment organizational, job statisfaction and employee performance is a high category. Commitment organizational has a positive and significant effect parttially on employee performance. Job satifactions has a positive and significant effect parttially on employee performance. Job satisfaction has a positive and significant effect purely on employee performance. Organizational commitment and job satisfaction together have a positive and significant effect simultaneously on employee performance.
\end{abstract}

Keywords: Organizational Organizational; Job Statisfaction; Employee Performance. 


\section{ENTREPRENEUR}

\section{Jurnal Bisnis Manajemen Dan Kewirausahaan}

Program Studi Manajemen Fakultas Ekonomika dan Bisnis Universitas Majalengka

Published every January and July e-ISSN : (2776-2483), p-ISSN: 2723-1941

Available online http://ejournal.unma.ac.id/index.php/entrepreneur

\section{PENDAHULUAN}

Sumber daya adalah segala sesuatu yang merupakan aset perusahaan untuk mencapai tujuannya. Sumber daya yang dimiliki perusahaan dapat dikategorikan atas empat sumber daya, seperti Finansial, Fisik, Manusia dan Kemampuan Teknologi. Dari keempat sumber tersebut aspek yang terpenting yaitu manusia, karena manusia merupakan penggerak terpenting dalam perusahaan.

Peranan karyawan sebagai sumber tenaga kerja dalam perusahaan sangat dibutuhkan dalam pengelolaan organisasi dan pelayanan publik termasuk PDAM Kabupaten Majalengka. Simanjutak dalam Ni Komang dan I Gede (2016:872) menyatakan bahwa kinerja setiap orang dipengaruhi oleh banyak faktor yang dapat digolongkan pada tiga kelompok, yaitu kompensasi individu yang bersangkutan, dukungan organisasi dan dukungan manajemen.

Saat ini bukan hanya faktor eksternal saja yang dapat mempengaruhi kinerja sebuah perusahaan, namun faktor internal lebih memiliki pengaruh dalam peningkatan atau penurunan kinerja sebuah perusahan. Demikian pula halnya dengan komitmen organisasional yang dimiliki oleh karyawan dalam perusahaan rendah tentu saja sangat memiliki pengaruh terhadap kinerja sebuah perusahaan.

Sopiah dalam Ni Komang dan I Gede (2016:872) menyatakan bahwa komitmen organisasional (organizational commitment) merupakan tingkat keyakinan karyawan untuk menerima tujuan organisasi sehingga berkeinginan untuk tetap tinggal dan menjadi bagian organisasi tersebut.

Menurut Mayer dalam Endik dan Herni (2018:104) mengemukakan bahwa ada tiga komitmen organisasional yaitu affective commitment, terjadi apabila karyawan ingin menjadi bagian dari organisasi karena adanya ikatan emosional, continuance commitment, muncul apabila karyawan tetap bertahan pada suatu organisasi karena membutuhkan gaji dan keuntungan-keuntungan lain, atau karena karyawan tersebut tidak menemukan pekerjaan lain, normative commitment, timbul dari nilai-nilai dalam diri karyawan. Tingginya komitmen akan berimbas pada kinerja karyawan yang semakin meningkat.

Mathis dan Jackson dalam Ni Komang dan I Gede (2016:874) seseorang karyawan yang semula kurang memiliki komitmen berorganisasi, namun setelah bekerja ternyata mendapatkan kepuasan kerja, akan menumpuk berkembangnya komitmen berorganisasi. Kepuasan kerja yang tinggi akan memengaruhi kualitas kerja yang baik dan dinamis sehingga dapat menguntungkan bagi perusahaan serta karyawan itu sendiri, selain itu kepuasan kerja adalah aspek pertama dalam membentuk komitmen organisasional.

PDAM merupakan perusahaan daerah sebagai sarana penyediaan air bersih yang diawasi dan dimonitori oleh aparat-aparat eksekutif maupun legislatif daerah. Pada awal pendiriannya bernama BPAM beralih menjadi PDAM berdasarkan Peraturan daerah No. 11 Tahun 1988 tanggal 18 Nopember 1988, dan sesuai dengan Peraturan daerah kabupaten mjalengka Nomor 26 Tahun 2001 tentang perubahan pertama atas Peraturan Daerah Kabupaten Majalengka Nomor 11 Tahun 1988, yang disesuaikan dengan Peraturan Menteri Dalam Negeri Nomor 47 Tahun 1999 tentang Pedoman Kinerja Perusahaan Daerah Air Minum dan Peraturan Daerah Kabupaten Majalengka Nomor 5 Tahun 2006 tentang Organisasi dan Tata Kerja Perusahaan Daerah Air Minum Kabupaten Majalengka. Kantor Pusat 


\section{ENTREPRENEUR}

Jurnal Bisnis Manajemen Dan Kewirausahaan

Program Studi Manajemen Fakultas Ekonomika dan Bisnis Universitas Majalengka

Published every January and July e-ISSN : (2776-2483), p-ISSN: 2723-1941

Available online http://ejournal.unma.ac.id/index.php/entrepreneur

Perusahaan Daerah Air Minum Kabupaten Majalengka memiliki karyawan sebanyak 51 orang dan 1 orang direktur.

Kinerja karyawan Kantor Pusat PDAM Kabupaten Majalengka dapat dilihat dalam evaluasi rencana dan anggaran perusahaan (RKAP) yang berisi laporan realisasi dan anggaran. Jumlah keseluruhan antara realisasi dan anggaran Kantor Pusat PDAM Kabupaten Majalengka mengalami selisih yang menguntungkan bagi perusahaan, RKAP Kantor Pusat PDAM Kabupaten Majalengka memiliki pencapaian di atas target yang ditetapkan oleh perusahaan. PDAM Kabupaten Majalengka mengadakan evaluasi laporan laba/rugi untuk membantu pihak perusahaan dalam menentukan langkah perusahaan selanjutnya.

\section{Tujuan Penelitian}

Penelitian ini bertujuan untuk mengetahui pengaruh komitmen organisasional terhadap kinerja karyawan, pengaruh kepuasan kerja terhadap kinerja karyawan dan pengaruh komitmen organisasional dan kepuasan kerja terhadap kinerja karyawan Kantor Pusat Perusahaan Daerah Air Minum Kabupaten Majalengka.

\section{KERANGKA TEORITIS DAN HIPOTESIS}

\section{Komitmen Organisasional}

Luthan dalam Jhony Taroreh (2018:37) menyatakan bahwa komitmen merupakan sikap yang menggambarkan kesetiaan karyawan terhadap perusahaan. Karyawan yang memiliki komitmen organisasional adalah karyawan yang mempunyai keinginan kuat untuk menjadi anggota utama dari organisasinya, mempunyai kemauan kuat untuk bekerja dan berusaha bagi kepentingan organisasi, mempunyai kepercayaan dan penerimaan terhadap nilai-nilai dan tujuan organisasi.
Allen dan Meyer dalam Ridwan (2018:39-40) membagi komitmen orgnaisasional menjadi 3 dimensi yang terdiri

a. Affective Commitment

b. Continuance Commitment

c. Normative Commitment

\section{Kepuasan Kerja}

Menurut Robbins dalam Arti Silviani (2019:41) menyatakan bahwa kepuasan kerja adalah suatu sikap umum terhadap pekerjaan seseorang sebagai perbedaan antara banyaknya ganjaran yang diterima pekerja dengan banyaknya ganjaran yang diyakini seharusnya diterima. Kepuasan kerja merupakan hal penting yang dimiliki individu di dalam bekerja. Setiap individu pekerja memiliki karakteristik yang berbeda, maka tingkat kepuasan kerjanya pun berbeda pula tinggi rendahya kepuasan kerja tersebut dapat memberikan dampak yang tidak sama.

Menurut Stephen P. Robbins diterjemahkan oleh wibowo dalam Arti Silviani (2019:54), dimensi dan indikator kepuasan kerja yaitu :

1. Pekerjaan itu sendiri (work it self), Indikator dari dimensi ini, yaitu:
a. Kepuasan terhadap kesesuaian pekerjaan dengan kemampuan yang dimiliki.
b. Kepuasan terhadap tanggung jawab yang diberikan dalam pekerjaan.
c. Kepuasan terhadap pekerjaan agar lebih kreatif.
d. Kepuasan untuk mendapat kesempatan belajar.

2. Gaji/Upah

Indikator dari dimensi ini, yaitu :
a. Kepuasan atas kesesuaian gaji dengan pekerjaan.
b. Kepuasan atas tunjangan yang diberikan.
c. Kepuasan atas pemberian insentif. 


\section{ENTREPRENEUR}

\section{Jurnal Bisnis Manajemen Dan Kewirausahaan}

Program Studi Manajemen Fakultas Ekonomika dan Bisnis Universitas Majalengka

Published every January and July e-ISSN : (2776-2483), p-ISSN: 2723-1941

Available online http://ejournal.unma.ac.id/index.php/entrepreneur

3. Supervisi

Indikator dari dimensi ini,yaitu:
a. Kepuasan atas bantuan teknis yang diberikan atasan.
b. Kepuasan atas dukungan moril yang diberikan atasan.
c. Kepuasan pengawasan yang dilakukan oleh atasan.

4. Rekan kerja

Indikator dari dimensi ini, yaitu :
a. Kepuasan atas kerjasama dalam tim.
b. Kepuasan atas lingkungan sosial dalam pekerjaan.

\section{Kinerja Karyawan}

Menurut Veithzal dalam Meitiana Indrasari (2017:50) bahwa kinerja merupakan hasil keterkaitan antara usaha, kemampuan dan presepsi tugas. Kinerja yang tinggi sebagai suatu langkah untuk menuju pada proses tercapainya tujuan organisasi bersangkutan.

Ranupandjo dan Hasan dalam Desak Ketut (2016:4) menungkapkan dimensi dan indikator kinerja meliputi:

1. Kualitas kerja. Terdiri dari empat indikator:
a. Ketepatan waktu
b. Ketelitian
c. Kemampuan
d. Keterampilan pegawai

2. Kuantitas kerja. Terdiri dari dua indikator yaitu:

a. Memenuhi standar kerja

\section{b. Pekerjaan rutin terlaksana dengan cepat}

3. Tingkat keandalan. Terdiri dari tiga indikator yaitu:
a. Inisiatif
b. Rajin
c. Kemampuan dalam bekerja

4. Sikap. Terdiri dari dua indikator yaitu:

a. Loyalitas dan tanggung jawab pegawai

b. Kerjasama tim

\section{METODELOGI PENELITIAN}

Metode yang digunakan dalam penelitian ini adalah metode survey dengan menggunakan pendekatan analisis deskriptif dan verikatif. Populasi penelitian adalah seluruh karyawan Kantor Pusat Perusahaan Daerah Air Minum Kabupaten Majalengka yang seluruhnya berjumlah 51 orang. Pengambilan sampel dilakukan dengan teknik sampling jenuh, yaitu seluruh populasi dijadikan sebagai sampel penelitian.

Pengujian instrumen penelitian menggunakan uji validitas dan uji reliabilitas. Analisis data yang digunakan adalah uji asumsi klasik, analisis regresi linear berganda, dan uji hipotesis. Pengujian hipotesis dalam penelitian ini menggunakan uji hipotesis parsial dan uji hipotesis simultan. Adapun paradigma hubungan antar variabel digambarkan sebagai berikut:

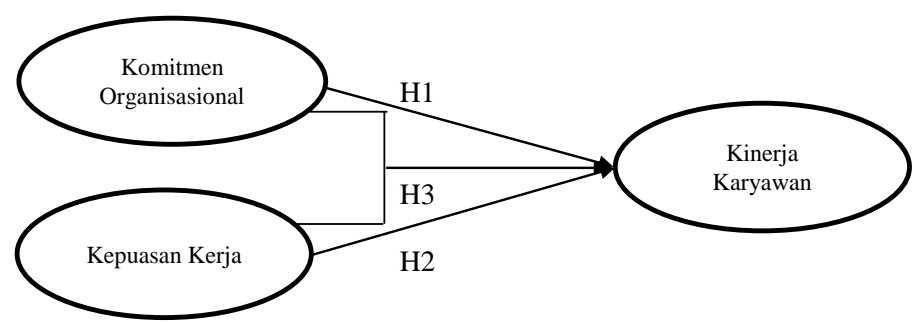

Gambar 1. Paradigma Hubungan Antar Variabel Penelitian 


\section{ENTREPRENEUR}

\section{Jurnal Bisnis Manajemen Dan Kewirausahaan}

Program Studi Manajemen Fakultas Ekonomika dan Bisnis Universitas Majalengka

Published every January and July e-ISSN : (2776-2483), p-ISSN: 2723-1941

Available online http://ejournal.unma.ac.id/index.php/entrepreneur

\section{Hipotesis}

$\mathrm{H}_{1}$ : Ada pengaruh Komitmen Organisasional terhadap Kinerja Karyawan

$\mathrm{H}_{2}$ : Ada pengaruh Kepuasan Kerja terhadap Kinerja Karyawan

$\mathrm{H}_{3}$ : Ada pengaruh Komitmen organisasional dan Kepuasan Kerja terhadap Kinerja Karyawan

\section{HASIL DAN PEMBAHASAN \\ Uji Instrumen Penelitian}

Uji validitas dalam penelitian ini dilakukan terhadap 22 pernyataan yang terdiri dari 6 pernyataan variabel komitmen organisasional, 8 pernyataan variabel kepuasan kerja dan 8 pernyataan variabel kinerja karyawan. Adapun kriteria yang digunakan untuk menilai validitas dari masing-masing pernyataan adalah jika $\mathrm{r}_{\text {hitung }}>\mathrm{r}_{\text {tabel. }}$ Berikut hasil uji validitas disajikan pada tabel 1.

Tabel 1. Uji Validitas

\begin{tabular}{|c|c|c|c|c|c|}
\hline \multirow[b]{2}{*}{ Pernyataan } & \multicolumn{3}{|c|}{ r-hitung } & \multirow{2}{*}{$\begin{array}{c}\mathbf{r}_{\text {tabel }}(0,05) \\
=n-2 \\
=51-2 \\
=49\end{array}$} & \multirow[b]{2}{*}{ Ket } \\
\hline & $\begin{array}{c}\text { Komitmen } \\
\text { organisasional } \\
\left(\mathbf{X}_{1}\right)\end{array}$ & $\begin{array}{c}\text { Kepuasan } \\
\text { Kerja } \\
\left(\mathbf{X}_{2}\right)\end{array}$ & $\begin{array}{c}\text { Kinerja } \\
\text { Karyawan } \\
(\mathbf{Y})\end{array}$ & & \\
\hline 1 & 0,384 & 0,496 & 0,553 & 0,275 & Valid \\
\hline 2 & 0,468 & 0,395 & 0,627 & 0,275 & Valid \\
\hline 3 & 0,309 & 0,398 & 0,642 & 0,275 & Valid \\
\hline 4 & 0,449 & 0,324 & 0,558 & 0,275 & Valid \\
\hline 5 & 0,352 & 0,286 & 0,575 & 0,275 & Valid \\
\hline 6 & 0,397 & 0,303 & 0,469 & 0,275 & Valid \\
\hline 7 & & 0,421 & 0,367 & 0,275 & Valid \\
\hline 8 & & 0,417 & 0,519 & 0,275 & Valid \\
\hline
\end{tabular}

Sumber: Output SPSS 22, 2021

Pada tabel 1 diatas diketahui seluruh variabel penelitian memiliki item pernyataan dengan nilai $r_{\text {hitung }}$ lebih besar dari nilai $r_{\text {tabel }}$ pada derajat signifikasi 0,05 . Sehingga dapat dinyatakan bahwa seluruh variabel memiliki konstruk atau item pernyatan yang valid sebagai alat ukur pengumpulan data penelitian.

Hasil uji reliabilitas tabel 2 menunjukan hasil uji reliabel sebagai berikut:

Tabel 2. Uji Reliabilitas

\begin{tabular}{lcccc}
\hline \multicolumn{1}{c}{ Variabel } & $\begin{array}{c}\text { Total Item } \\
\text { Pernyataan }\end{array}$ & Nilai cronbach & $\begin{array}{c}\text { Nilai } \\
\text { Kritis }\end{array}$ & Keterangan \\
\hline Komitmen Organisasional & 6 & 0,658 & 0,6 & Reliabel \\
\hline Kepuasan Kerja & 8 & 0,680 & 0,6 & Reliabel \\
\hline Kinerja Karyawan & 8 & 0,819 & 0,6 & Reliabel \\
\hline
\end{tabular}

Sumber: Output SPSS 22, 2021

Hasil uji cronbach's alpha sebagaimana disajikan pada tabel 2 diatas menunjukkan bahwa seluruh variabel penelitian memiliki nilai cronbach's alpha yang lebih besar dari nilai kritis 0,06. Dengan demikian dapat dinyatakan bahwa 


\section{ENTREPRENEUR}

\section{Jurnal Bisnis Manajemen Dan Kewirausahaan}

Program Studi Manajemen Fakultas Ekonomika dan Bisnis Universitas Majalengka

Published every January and July e-ISSN : (2776-2483), p-ISSN: 2723-1941

Available online http://ejournal.unma.ac.id/index.php/entrepreneur

instrumen penelitian yang berupa kuisioner memiliki kehandalan untuk mengumpulkan data penelitian.

\section{Uji Normalitas Data}

Hasil uji normalitas data dapat dilihat dalam tabel sebagai berikut:

Tabel 3. Hasil Uji Normalitas Data

One-Sample Kolmogorov-Smirnov Test

\begin{tabular}{llr}
\hline & & Unstandardized_Residual \\
\hline N & & 49 \\
\cline { 2 - 3 } & Mean & 26.0392 \\
\cline { 2 - 3 } & Std. Deviation & 3.62313 \\
\hline Most Extreme Differences & Absolute & .090 \\
\cline { 2 - 3 } & Positive & .090 \\
\cline { 2 - 3 } & Negative & -.079 \\
\hline Test Statistic & & .090 \\
\hline Asymp. Sig. (2-tailed) & & $.200^{c, d}$ \\
\hline
\end{tabular}

a. Test distribution is Normal.

b. Calculated from data.

c. Lilliefors Significance Correction.

$\mathrm{d}$. This is a lower bound of the true significance.

Sumber: Output SPSS 22, 2021

Berdasarkan tabel 3 dapat diketahui bahwa nilai asymp.Sig. (2-tailed) adalah 0,200 menunjukan nilai signifikasi yang

lebih dari $\alpha=0,05$ sehingga dapat dikatakan data dalam penelitian ini berdistribusi normal.

\section{Tabel 4. Hasil Uji Multikolinearitas}

\section{Coefficients $^{\text {a }}$}

\begin{tabular}{|c|c|c|c|c|c|c|c|}
\hline \multirow[t]{2}{*}{ Model } & \multicolumn{2}{|c|}{$\begin{array}{l}\text { Unstandardized } \\
\text { Coefficients }\end{array}$} & \multirow{2}{*}{$\begin{array}{c}\begin{array}{r}\text { Standardized } \\
\text { Coefficients }\end{array} \\
\text { Beta }\end{array}$} & \multirow[b]{2}{*}{$\mathbf{t}$} & \multirow[b]{2}{*}{ Sig. } & \multicolumn{2}{|c|}{ Collinearity Statistics } \\
\hline & B & Std. Error & & & & Tolerance & VIF \\
\hline Constant) & .171 & 2.860 & & .060 & .953 & & \\
\hline omitmen_organisasional & .287 & .126 & .215 & 2.277 & .027 & .852 & 1.174 \\
\hline epuasan_kerja & .794 & .107 & .699 & 7.405 & .000 & .852 & 1.174 \\
\hline
\end{tabular}

a. Dependent Variable: kinerja_karyawan

Sumber: Output SPSS 22, 2021

Tabel 4 menunjukkan bahwa nilai tolerance dari variabel Komitmen Organisasional dan kepuasan kerja lebih besar dari 0,10 dan nilai VIF lebih kecil dari 10,00 sehingga dapat disimpulkan tidak terjadi multikolinearitas.

Tabel 5. Hasil Uji Autokolerasi Model Summary ${ }^{b}$

\begin{tabular}{cccccc}
\hline Model & $\mathbf{R}$ & R Square & Adjusted R Square & $\begin{array}{c}\text { Std. Error of the } \\
\text { Estimate }\end{array}$ & Durbin-Watson \\
\hline 1 & $.807^{\mathrm{a}}$ & .651 & .635 & 2.71204 & 1.870 \\
\hline
\end{tabular}

a. Predictors: (Constant), kepuasan_kerja, komitmen_organisasional

b. Dependent Variable: kinerja_karyawan

Sumber: Output SPSS 22, 2021

Berdasarkan hasil uji autokolerasi didapat nilai batas atas (dU) yaitu 1,675 lebih kecil dari nilai d (Durbin-Watson) yaitu 1,870 dan kurang dari (4-dU) 4-1,427= 2,352. Maka dapat disimpulkan bahwa pada penelitian ini tidak ada gejala autokolerasi. 


\section{ENTREPRENEUR}

\section{Jurnal Bisnis Manajemen Dan Kewirausahaan}

Program Studi Manajemen Fakultas Ekonomika dan Bisnis Universitas Majalengka

Published every January and July e-ISSN : (2776-2483), p-ISSN: 2723-1941

Available online http://ejournal.unma.ac.id/index.php/entrepreneur

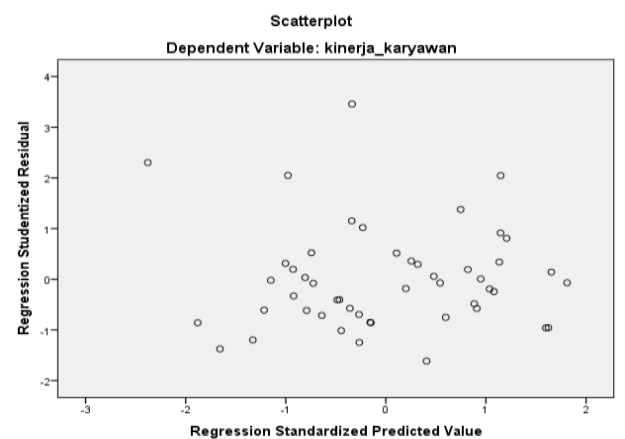

Gambar 3. Hasil Uji Heteroskedastisitas

Berdasarkan grafik scatterplot menunjukkan bahwa titik-titik data menyebar baik diatas dan dibawah angka 0 pada sumbu $Y$ serta titik-titik data tidak

hanya mengumpul di atas dan dibawah, hal ini dapat disimpulkan bahwa tidak terdapat Heteroskedastisitas.

Tabel 6. Uji regresi linier berganda Coefficients $^{\mathrm{a}}$

\begin{tabular}{|c|c|c|c|c|c|c|c|c|c|c|c|}
\hline \multirow{2}{*}{\multicolumn{2}{|c|}{ Model }} & \multicolumn{2}{|c|}{$\begin{array}{c}\text { Unstandardized } \\
\text { Coefficients }\end{array}$} & \multirow{2}{*}{$\begin{array}{c}\begin{array}{c}\text { Standardized } \\
\text { Coefficients }\end{array} \\
\text { Beta }\end{array}$} & \multirow{2}{*}{$\mathbf{T}$} & \multirow{2}{*}{ Sig. } & \multicolumn{3}{|c|}{ Correlations } & \multicolumn{2}{|c|}{$\begin{array}{c}\text { Collinearity } \\
\text { Statistics }\end{array}$} \\
\hline & & B & Std. Error & & & & $\begin{array}{l}\text { Zero- } \\
\text { order }\end{array}$ & Partial & Part & $\begin{array}{c}\text { Tolera } \\
\text { nce }\end{array}$ & VIF \\
\hline \multirow[t]{3}{*}{1} & (Constant) & .171 & 2.860 & & .060 & .953 & & & & & \\
\hline & $\begin{array}{l}\text { komitmen_organi } \\
\text { sasional }\end{array}$ & .287 & .126 & .215 & 2.277 & .027 & .484 & .318 & .198 & .852 & 1.174 \\
\hline & kepuasan_kerja & .794 & .107 & .699 & 7.405 & .000 & .782 & .737 & .645 & .852 & 1.174 \\
\hline
\end{tabular}

a. Dependent Variable: kinerja_karyawan

Sumber: Output SPSS 22, 2021

Berdasarkan tabel 6 tersebut diketahui bahwa persamaan regresi linear berganda dalam penelitian ini adalah :

$$
\mathrm{Y}=0,171+0,287 X_{1}+0,794 X_{2}+\varepsilon
$$

1. Konstanta (a) dalam regresi sebesar 0,171 dan bertanda positif artinya jika semua variabel bebas (komitmen organisasional dan kepuasan kerja) memiliki nilai nol (0) maka nilai Loyalitas sebesar 0,171 tanpa adanya pengaruh dari variabel bebas.

2. Koefisien regresi komitmen organisasional 0,287 dan bertanda positif, artinya jika komitmen organisasional tinggi akan meningkatkan kinerja karyawan, begitu pula sebaliknya.

3. Koefisien regresi kepuasan kerja 0,794 dan bertanda positif, artinya jika kepuasan kerja tinggi maka akan meningkatkan kinerja karyawan, begitu pula sebaliknya.

4. Nilai residual $(\varepsilon)$ artinya error bahwa kesalahan dalam memprediksi data sampel yang dilakukan oleh peneliti.

\section{UJI HIPOTESIS}

Uji Parsial

Hasil uji t dalam penelitian ini disajikan dalam tabel 7 sebagai berikut:

Berdasarkan tabel 6 diperoleh nilai $t_{\text {hitung variabel komitmen organisasional }}$ sebesar 2,277 dan kepuasan kerja sebesar 7,405 dengan $t_{\text {hitung }}$ sebesar 2,009 sehingga dapat disimpulkan bahwa $t_{\text {tabel }}>t_{\text {hitung. }}$. Artinya terdapat pengaruh secara parsial antara komitmen organisasional dan kepuasan kerja terhadap kinerja. 


\section{ENTREPRENEUR}

\section{Jurnal Bisnis Manajemen Dan Kewirausahaan}

Program Studi Manajemen Fakultas Ekonomika dan Bisnis Universitas Majalengka

Published every January and July e-ISSN : (2776-2483), p-ISSN: 2723-1941

Available online http://ejournal.unma.ac.id/index.php/entrepreneur

\section{Uji Simultan}

Uji simultan atau uji F digunakan untuk mengetahui apakah variabel independen (komitmen organisasional dan kepuasan kerja) secara simultan dapat mempengaruhi variabel dependen (kinerja karyawan). Hasil uji $\mathrm{t}$ dalam penelitian ini disajikan dalam tabel 7 sebagai berikut:

Tabel 7. Hasil Uji Simultan

\begin{tabular}{llrrrrr}
\multicolumn{8}{c}{ ANOVA } \\
\hline & Model & Sum of Squares & Df & Mean Square & F & \multicolumn{1}{c}{ Sig. } \\
\hline \multirow{2}{*}{1} & 630.099 & 2 & 315.049 & 42.834 & $.000^{\mathrm{b}}$ \\
\cline { 2 - 7 } & Regression & 338.338 & 46 & 7.355 & & \\
\cline { 2 - 7 } & Residual & 968.436 & 48 & & & \\
\cline { 2 - 7 } & Total & 96 & & &
\end{tabular}

a. Dependent Variable: kinerja_karyawan

b. Predictors: (Constant), kepuasan_kerja, komitmen_organisasional

Sumber: Output SPSS 22, 2021

Berdasarkan tabel 7 hasil uji simultan diperoleh nilai $F_{\text {hitung }}>F_{\text {tabel }}$ yaitu 42,834>3,19 maka Ho ditolak. Artinya komitmen organisasional dan kepuasan kerja berpengaruh positif dan signifikan terhadap kinerja karyawan.

\section{PEMBAHASAN}

\section{Pengaruh Komitmen Organisasional terhadap Kinerja Karyawan}

Berdasarkan hasil pengujian hipotesis secara parsial $t_{\text {hitung }}>\mathrm{t}_{\text {tabel }}$ maka $\mathrm{H}_{0}$ ditolak. Dengan demikian dapat disimpulkan bahwa hipotesis pertama komitmen organisasional berpengaruh signifikan terhadap kinerja karyawandan diterima kebenarannya Artinya semakin tinggi komitmen organisasional maka akan semakin tinggi pula kinerja karyawan Kantor Pusat PDAM Kabupaten Majalengka.

\section{Pengaruh Kepuasan Kerja terhadap Kinerja Karyawan}

Berdasarkan hasil pengujian hipotesis secara parsial $t_{\text {hitung }}>t_{\text {tabel }}$ maka $\mathrm{H}_{0}$ ditolak. Dengan demikian dapat disimpulkan bahwa hipotesis kedua kepuasan kerja berpengaruh signifikan terhadap kinerja karyawan dan diterima kebenarannya. Artinya semakin tinggi kepuasan kerja maka akan semakin tinggi pula kinerja karyawan Kantor Pusat PDAM Kabupaten Majalengka.

\section{Pengaruh Komitmen Organisasional dan Kepuasan Kerja terhadap Kinerja Karyawan}

Berdasarkan hasil pengujian hipotesis secara simultan $t_{\text {hitung }}>t_{\text {tabel }}$ maka $\mathrm{H}_{0}$ ditolak. Dengan demikian dapat disimpulkan bahwa hipotesis ketiga komitmen organisasional dan kepuasan kerja berpengaruh signifikan terhadap kinerja karyawan diterima dan kebenarannya. Artinya semakin tinggi komitmen organisasional dan kepuasan kerja maka akan semakin tinggi pula kinerja karyawan Kantor Pusat PDAM Kabupaten Majalengka.

\section{SIMPULAN DAN IMPLIKASI SIMPULAN}

Berdasarkan hasil penelitian yang telah dilakukan, dapat disimpulkan bahwa komitmen organisasional memiliki pengaruh positif dan signifikan terhadap kinerja karyawan; kepuasan kerja memiliki pengaruh positif dan signifikan terhadap kinerja karyawan; komitmen organisasional dan kepuasan kerja memiliki pengaruh 


\section{ENTREPRENEUR}

\section{Jurnal Bisnis Manajemen Dan Kewirausahaan}

Program Studi Manajemen Fakultas Ekonomika dan Bisnis Universitas Majalengka

Published every January and July e-ISSN : (2776-2483), p-ISSN: 2723-1941

Available online http://ejournal.unma.ac.id/index.php/entrepreneur

positif dan signifikan terhadap kinerja karyawan.

\section{IMPLIKASI}

Untuk meningkatkan kinerja karyawan Kantor Pusat Perusahaan Daerah Air Minum Kabupaten Majalengka hendaknya karyawan dapat menyelesaikan masalah organisasi sebagai bentuk tanggung jawab karyawan terhadap organisasi sehingga masalah yang terjadi dapat diselesaikan dengan cepat; perusahaan atau atasan dapat memberikan gaji sesuai dengan pekerjaan yang diberikan; karyawan bekerja sesuai dengan waktu atau aturan yang sudah ditetapkan oleh perusahaan; selain itu untuk peneliti selanjutnya dapat menggunakan metode lain dan teknik sampling lain dalam melakukan penelitian serta menggunakan objek penelitian yang lebih luas dan berbeda dan lokasi penelitian sebelumnya.

\section{DAFTAR PUSTAKA}

Arti Silviani. (2019). Pengaruh Stres Kerja, Kepuasan Kerja dan Lingkungan Kerja Terhadap Kinerja Perawat RSUD Pantura M.A Sentot Patrol Indramayu. Skripsi. Program Studi Manajemen. Fakultas Ekonomi dan Bisnis. Universitas Pasundan Bandung.

Desak Ketut Ratna Dewi, I Wayan Suwendra., \& Ni Nyoman Yulianthini, (2016), Pengaruh Tingkat Pendidikan dan Motivasi Kerja Terhadap Kinerja Karyawan, Jurnal Manajemen, Vol 4, 1-10.
Endik Sunaryo \& Herni Widiyah Nasrul, (2018), Pengaruh Kepuasan Kerja dan Komitmen Organisasional Terhadap Kinerja Karyawan PT. Philips Batam, Jurnal Dimensi, Vol 7 No 1, 100-120.

Jhony Taroreh. (2018). Pemberdayaan Masyarakat, Learning Organization, Komitmen Organisasional (Studi Kasus UMKM). Yayasan Makaria Waya. Manado.

Meitiana Indrasari. (2017). Kepuasan Kerja dan Kinerja Karyawan. Indomedia Pustaka, Yogyakarta.

Ni Komang Sri Wahyudi., I Gede Adyana Sudibya. 2016. Pengaruh kepuasan kerja dan komitmen organisasional pada kinerja karyawan di Natya Hotel, Kuta Bali. E-Jurnal Manajemen Unud. Vol 5 No 2, 870-897.

Ridwan Rizki Saputro. 2018. Pengaruh Komitmen Afektif, Komitmen berkelanjutanan, dan Komitmen Normatif terhadap Kinerja Karyawan dengan Organizational Citizenship Behavior sebagai Variabel Intervening di Adira Finance Yogyakarta. Skripsi. Fakultas Ekonomi. Universitas Islam Indonesia Yogyakarta.

Siregar Braham, 2017, Memahami Manajemen Sumber Daya Manusia. Jurnal Ilmiah Simantek, Vol 1 No 2, 31-39. 